\section{SELECTION OF SAFETY OFFICERS IN AN INDIAN CONSTRUCTION ORGANIZATION BY USING GREY RELATIONAL ANALYSIS}

Sunku Venkata Siva Rajaprasad National Institute of Construction Management and Research, India E-mail: sunku.vsrp@gmail.com

Submission: 05/04/2017

Revision: 11/05/2017

Accept: 28/06/2017

\title{
ABSTRACT
}

Stakeholders are responsible for implementing the occupational health and safety provisions in an organization. Irrespective of organization, the role of safety department is purely advisory as it coordinates with all the departments, and this is crucial to improve the performance. Selection of safety officer is vital job for any organization; it should not only be based on qualifications of the applicant, the incumbent should also have sufficient exposure in implementing proactive measures. The process of selection is complex and choosing the right safety professional is a vital decision. The safety performance of an organization relies on the systems being implemented by the safety officer. Application of multi criteria decision-making tools is helpful as a selection process. The present study proposes the grey relational analysis(GRA) for selection of the safety officers in an Indian construction organization. This selection method considers fourteen criteria appropriate to the organization and has ranked the results. The data was also analyzed by using technique for order Preference by Similarity to an Ideal solution (TOPSIS) and results of both the methods are strongly correlated.

Keywords: Safety officer, Occupational health, GRA, Selection criteria,TOPSIS 


\section{INTRODUCTION}

The role of safety officers is imperative for any type of organizations to avoid accidents. The objectives of safety policy and management's commitment towards occupational health and safety issues can be implemented effectively only by the efforts of the safety officers. Majority of the construction organizations in India are forced to employ safety officers based on their previous experience without considering qualifications.

The important safety activities such as hazard identification and risk assessment, imparting trainings, implementing engineering controls, conducting investigations, developing safety culture and standard operating procedures is a daunting task due to lack of qualified safety officers. Majority of the Indian construction organizations are relying on external agencies to impart safety trainings to employees due to inadequate competency levels of safety officers, employed with them.

This is persisting even in higher cadres of safety department in Indian construction industry. The results of the study conducted in Sri Lanka emphasized the need for appointment of full time safety officers to improve safety performance (KANCHANA, et al., 2014). Lack of expertise and knowledge on part of the safety officers in implementing hierarchy of accident prevention controls is a major concern to the construction organizations.

A study conducted in India suggest that perception of safety officers from construction steel and refractory industries has positive influence on factors such as injury avoidance, work practices, standardisation, healthcare and risk management (BERIHA, et al., 2011). The role of safety officer is significant in improving safety performance and the selection of safety officer is an important decision for any organization.

Some organizations adopt expensive and time-consuming processes for selecting the suitable personnel, while others complete the recruitment process faster with less expense using traditional methods of selection based on criteria like expertise and qualifications. The traditional methods yeild results based on subjective judgment of decision makers, which makes the accuracy of the results questionable. 
INDEPENDENT JOURNAL OF MANAGEMENT \& PRODUCTION (IJM\&P)

http://www.ijmp.jor.br

v. 9, n. 1, January - March 2018

ISSN: 2236-269X

DOI: 10.14807/ijmp.v9i1.656

In order to select the most suitable personnel, combining the 'Subjective Judgment' and 'The Objective Analysis' approaches is the need of the hour in the current business environment (PRAMANIK; MUKHOPADHYAYA, 2011). It is observed from the literature that various methods are proposed for personnel selection, to assist the organizations in this key decision making process. Most of these methods are multi criterion decision making methods (MCDM).

Liang and Wang presented a fuzzy MCDM algorithm for personnel selection (LIANG; WANG, 1994). Gibney and Shang have advised the use of the analytical hierarchy process (AHP) in the personnel selection process (GIBNEY; SHANG, 2007). Dağdeviren proposed a hybrid model, which employs analytical network process (ANP) and modified technique for order preference by similarity to ideal solution (TOPSIS) for supporting the personnel selection process in the manufacturing systems (DAGDEVIREN,2010).

Robertson and Smith presented reviews on personnel selection studies and investigated the role of job analysis and other contemporary models of work performance, and set of criteria used in personnel selection process (ROBERTSON; SMITH, 2001).

Managers in an organization make decisions in a static and stochastic environment. Right decisions are possible in a stochastic environment, which is closer to the reality and can be solved by applying grey relational analysis (GRA) (MARKABI; SABBAGH, 2014).

The solution of the problems with qualitative and quantitative data under complex criteria, uncertainty and insufficient data or information in decision making process is solved by using GRA (IRFAN, et al., 2016). GRA is one of the popular methods to analyze various relationships among the discrete data sets and make decisions in multi attribute situations and also useful to making decisions in complex business environment (SUNITHA; RUBEN, 2017).

The comparative analysis of different methods of personnel selection may help in finding out their accuracy, appropriateness, suitability, fairness and practical efficiency (ROUYENDEGH; ERKAN, 2012). In the present study, GRA was adopted to select safety professionals in Indian construction organizations and the results of the selection process were compared by using TOPSIS. 
DOI: 10.14807/ijmp.v9i1.656

\section{CONSTRUCTION SAFETY OFFICER}

The building and other construction workers act 1996 is the comprehensive legislation to regulate the employment and conditions of service of building and construction workers and to provide them safety, health and welfare measures. It is clearly mentioned in the building and other construction workers act, 1996 that every construction organization wherein five hundred or more building workers are ordinarily employed shall appoint safety officers (GOI, 1996). The act also specifies that the number of safety officers required is based on the strength of workers, qualifications of safety officers and; roles \& responsibilities.

The responsibilities of a construction safety officer as per the act are to conduct safety inspections, investigate all fatal and other selected accidents; maintenance of records with regard to accidents and occupational diseases; advise purchase department and ensure quality personal protective equipment confirming to Indian standards; promoting the functioning of safety committees; implementing motivational schemes; design and conducting safety training and educational programmes; framing safety rules and advise the supervisors in implementing safe operating procedures. Safety officers shall not be permitted to perform any work which is not relevant or detrimental to the performance of the roles and responsibilities.

\section{METHODOLOGY}

\subsection{Grey relational analysis and applications}

The information that is either incomplete or undetermined is called Grey. The Grey system provides multidisciplinary approaches for analysis and abstract modelling of systems for which the information is limited, incomplete and characterized by random uncertainty (SIFEN; FORREST, 2007). GRA has been extensively adopted by researches in various selection processes. The application of GRA in various field are presented in Table 1.

Table 1: Applications of GRA

\begin{tabular}{|l|l|}
\hline \multicolumn{1}{|c|}{ Area of application } & \multicolumn{1}{c|}{ Reference } \\
\hline Vendor evaluation & TSAI, et al., 2003 \\
\hline Supplier selection & YANG; CHEN, 2006 \\
\hline Material selection & CHAN; TONG, 2007 \\
\hline Performance of power plants & XU,et al., 2011 \\
\hline
\end{tabular}


DOI: 10.14807/ijmp.v9i1.656

\begin{tabular}{|l|l|}
\hline Supplier selection & RAJESH; RAVI,2015] \\
\hline Green supplier selection & HASHEMI,et al., 2015 \\
\hline Personnel selection & NILSEN,2016 \\
\hline Facilility layout & KUO, et al.,2008 \\
\hline Site selection & BIRGUN; GUNGOR,2014 \\
\hline
\end{tabular}

\subsection{Step by step procedure}

Step 1: Collection of data and forming decision matrix

The decision matrix $D_{a}$ is formed with $m$ alternatives and $n$ criteria is shown in Equation (1).

$$
\mathrm{D}_{\mathrm{a}}=\left[\begin{array}{l}
p_{1}(1), p_{1}(2), \ldots . . p_{1}(n) \\
p_{2}(1), p_{2}(2), \ldots . p_{2}(n) \\
\ldots . \\
\ldots . \\
p_{m}(1), p_{m}(2), \ldots . p_{m}(n)
\end{array}\right]
$$

Where, $p_{a}(k)$ is the value of $a^{\text {th }}$ alternative with respect to $b^{\text {th }}$ criterion.

Step 2: Normalization of the decision matrix

The standardized formula is suitable for the benefit or maximization is shown in Equation (2).

$\mathrm{p}_{a}{ }^{*}=\left[\mathrm{p}_{\mathrm{a}}(\mathrm{b})-\min \mathrm{p}_{\mathrm{a}}(\mathrm{b})\right] /\left[\operatorname{maxp} \mathrm{a}(\mathrm{b})-\min \mathrm{p}_{\mathrm{a}}(\mathrm{b})\right]$

The normalized formula for minimization criteria is shown in Equation 3.

$p_{a}{ }^{*}=\left[\max p_{a}(b)-p_{a}(b)\right] /\left[\max p_{a}(b)-\min p_{a}(b)\right]$

The medium - type, or nominal-the-best (the nearer to a certain standard value the better), if the target value is $p_{o c}(b)$ and $\max p_{a}(b)$ and $\max p a(b) \geq p o c(b)$ $\geq \min \mathrm{p}_{\mathrm{a}}(\mathrm{b})$, normalization formula is shown as equation (4).

$p_{a}^{*}=\left[\left|p_{a}(b)-p_{o c}(b)\right|\right] /\left[\max p_{a}(b)-p_{o c}(b)\right]$

Step 3: Developing reference series

The reference value the $b^{\text {th }}$ criterion $p_{0}^{*}(b)$ is determined by considering the maximum normalized value of each criterion by using the Equation (5).

$\mathrm{p}_{\mathrm{o}}^{*}(\mathrm{~b})=\max \left\{\mathrm{p}_{\mathrm{a}}(\mathrm{b})\right\}$ 
Step 4: Developing the difference matrix

The absolute difference of the compared series and the referential series should be obtained by using the following Equation (6).

$\Delta_{o a}(b)=\left|p_{o}^{*}(b)-p_{a}^{*}(b)\right|$ and the maximum and the minimum difference should be found.

Step 5 : Calculation of grey relation coefficient

$$
Y_{o a}(b)=\left[\left(\Delta_{\min }+\zeta \Delta_{\max }\right) /\left(\Delta_{\mathrm{oa}}(\mathrm{b})+\zeta \Delta_{\max }\right)\right]
$$

$\zeta$ is distinguishing coefficient and usually the value is considered by the decision makers as 0.5 as this value offers stability and distinguishing effects (ÖZCELIK; ÖZTURK,2014).

Step 6: Calculation of degree of grey coefficient (Гоа )

If the criteria weights are equal, then degree of grey coefficient is calculated by using Equation (8).

$$
\Gamma_{\text {oa }}=(1 / \mathrm{n}) \sum_{\mathrm{b}=1}^{\mathrm{n}} \text { Yoa }(\mathrm{b})
$$

If the weights of the criteria are different then grey coefficient is calculated by using Equation (9).

$$
\Gamma_{0 a}=\sum_{b=1}^{n} Y_{0 a}(b) w(b)
$$

$w(b)$ is the weight of the $j^{\text {th }}$ criteria and sum of $w(b)$ is one.

Step 7: Final selection and ranking

The selection and ranking of alternatives is according to the degree of grey coefficient and the alternative with highest grey coefficient will be the best alternative.

\subsection{Technique for order preference by similarity to an ideal solution (TOPSIS)}

TOPSIS is a multi criteria decision making tool. The principle of TOPSIS aims at devising an alternate solution, which should be nearest to the positive ideal solution and far away from the negative ideal solution. The ideal solution is formed 
as a composite of the best performance values in the decision matrix by any alternative for each attribute. The negative ideal solution is the composite of the worst performance values. The positive ideal solution is a solution that maximizes the benefit criteria and minimizes cost criteria and vice versa in case of the negative ideal solution. TOPSIS was adopted to ascertain the ranking of sectors based on safety performance. TOPSIS has been applied in various areas of research, and few applications are presented in Table 2.

Table 2: Application of TOPSIS

\begin{tabular}{|l|l|}
\hline \multicolumn{1}{|c|}{ Area of Application } & \multicolumn{1}{c|}{ Authors } \\
\hline $\begin{array}{l}\text { To provide decision methods for project managers in construction } \\
\text { organizations, which can be applied in other organizations also in project } \\
\text { selection issues. }\end{array}$ & PRAPAWAN, 2015 \\
\hline $\begin{array}{l}\text { To measure and compare the financial performance of firms trading in } \\
\text { stock exchange. }\end{array}$ & BERNA,2012 \\
\hline To compare multi criteria decision making tools to rank banks in Serbia. & DRAGSIA,et al.,2013 \\
\hline $\begin{array}{l}\text { To evaluate and select best location for implementing the urban } \\
\text { distribution centre. }\end{array}$ & ANJALI, et al.,2011 \\
\hline $\begin{array}{l}\text { To identify the factors influencing successful implementation of safety } \\
\text { management system. }\end{array}$ & HADI, et al.,2011 \\
\hline $\begin{array}{l}\text { To improve the process of supply chain management in a manufacturing } \\
\text { company. }\end{array}$ & $\begin{array}{l}\text { ROGHANIAN, et } \\
\text { al.,2014 }\end{array}$ \\
\hline To propose a method for supply chain risk evaluation. & SUN, et al., 2015 \\
\hline $\begin{array}{l}\text { To propose a method to assist contractors to make a better decision on } \\
\text { project selection. }\end{array}$ & $\begin{array}{l}\text { YONG - TAO et } \\
\text { al.,2010 }\end{array}$ \\
\hline $\begin{array}{l}\text { To identify best alternative basing on noise emitted from electrical } \\
\text { machines. }\end{array}$ & PIJUSH, et al., 2012 \\
\hline To explore new directions in telecom service quality in India. & AMIT; INDU,2013 \\
\hline To search for optimal tenderer in E -tendering. & WANG, et al., 2015 \\
\hline
\end{tabular}

\subsubsection{TOPSIS procedure}

The sequence of steps involved in TOPSIS procedure is detailed below:

Step 1: Arrange the attributes influencing safety performance.

Step 2: Construction of the decision matrix.

Step 3: Standardized evaluation matrix

Step 4: Construct weighted normalized decision matrix

Step 5: Construct weighted normalized matrix

Step 6: Calculation of separation of each alternative from the positive and negative ideal solutions

Step 7: The relative closeness index 
ISSN: 2236-269X

DOI: 10.14807/ijmp.v9i1.656

Step 8: Allocation of rankings

\section{SELECTION OF SAFETY OFFICER - A CASE STUDY}

A major construction organization in India was planning to recruit a safety officer with five years of experience in handling safety aspects in metro rail construction. The client was particular about qualifications of safety officer as per the BOCW Act, 1996 and communicated the fourteen criteria relating to the occupational heath and safety to be fulfilled by the safety officers. The requirements of client in selection of safety officer are presented in Table 3.

Table 3: Criteria for selection of safety officer

\begin{tabular}{|l|l|}
\hline$R_{1}$ Command over language & $\mathrm{R}_{8}$ Planning and organizing resources \\
\hline $\mathrm{R}_{2}$ Exposure in risk assessment & $\mathrm{R}_{9}$ Capable to work independently \\
\hline $\mathrm{R}_{3}$ Developing safe working procedures & $\mathrm{R}_{10}$ Steps to improve safety performance \\
\hline $\mathrm{R}_{4}$ Competency in imparting trainings & $\mathrm{R}_{11}$ Knowledge in OHS \\
\hline $\mathrm{R}_{5}$ Conducting mock drills & $\mathrm{R}_{12}$ Safety performance appraisal \\
\hline $\mathrm{R}_{6}$ Conducting accident investigations & $\mathrm{R}_{13}$ Initiatives to improve safety culture \\
\hline $\mathrm{R}_{7}$ Team work & $\mathrm{R}_{14}$ Knowledge in applicable legislations \\
\hline
\end{tabular}

Accordingly the organization released an advertisement in news papers and in response to the advertisement, 32 applications were received. On scrutiny of applications and after examining the relevant experience, age, qualifications; 9 applications were finalized. The 9 candidates were called for an interview to gauge the fulfillment of criteria. The panel comprising of three members; safety manager from client, safety head of contractor and an independent safety consultant; and the panel members were requested to rate each criteria on 1 to 5 scale with 1 corresponds to very low and 5 as very high.

\section{RESULTS}

\subsection{Results of GRA}

The common rating of the panel members after discussions, the final ratings were presented in the form of decision matrix and are presented in Table 4.

Table 4: Decision matrix

\begin{tabular}{|c|c|c|c|c|c|c|c|c|c|c|c|c|c|c|}
\hline & $\mathrm{R}_{1}$ & $\mathrm{R}_{2}$ & $\mathrm{R}_{3}$ & $\mathrm{R}_{4}$ & $\mathrm{R}_{5}$ & $\mathrm{R}_{6}$ & $\mathrm{R}_{7}$ & $\mathrm{R}_{8}$ & $\mathrm{R}_{9}$ & $\mathrm{R}_{10}$ & $\mathrm{R}_{11}$ & $\mathrm{R}_{12}$ & $\mathrm{R}_{13}$ & $\mathrm{R}_{14}$ \\
\hline S1 & 3 & 5 & 3 & 3 & 4 & 3 & 4 & 2 & 3 & 4 & 4 & 3 & 4 & 3 \\
\hline S2 & 4 & 4 & 2 & 4 & 3 & 3 & 3 & 4 & 3 & 5 & 3 & 4 & 3 & 3 \\
\hline S3 & 3 & 4 & 4 & 3 & 4 & 4 & 4 & 2 & 3 & 4 & 4 & 5 & 3 & 3 \\
\hline S4 & 2 & 5 & 3 & 3 & 3 & 4 & 3 & 3 & 4 & 4 & 3 & 4 & 3 & 3 \\
\hline S5 & 3 & 4 & 2 & 3 & 2 & 3 & 4 & 3 & 4 & 4 & 3 & 4 & 5 & 4 \\
\hline S6 & 4 & 3 & 3 & 3 & 3 & 3 & 3 & 5 & 2 & 3 & 3 & 4 & 4 & 3 \\
\hline S7 & 3 & 2 & 3 & 4 & 5 & 2 & 3 & 3 & 3 & 4 & 4 & 3 & 4 & 3 \\
\hline S8 & 2 & 4 & 3 & 3 & 5 & 4 & 3 & 3 & 3 & 4 & 4 & 3 & 4 & 2 \\
\hline S9 & 4 & 4 & 2 & 3 & 3 & 5 & 4 & 4 & 3 & 3 & 4 & 2 & 3 & 4 \\
\hline
\end{tabular}


ISSN: 2236-269X

DOI: 10.14807/ijmp.v9i1.656

\begin{tabular}{|l|l|l|l|l|l|l|l|l|l|l|l|l|l|l|}
\hline Ref & 1 & 1 & 1 & 1 & 1 & 1 & 1 & 1 & 1 & 1 & 1 & 1 & 1 & 1 \\
\hline
\end{tabular}

The normalized decision matrix was obtained by using the Equation (2) and presented in Table 5.

Table 5: Normalized decision matrix

\begin{tabular}{|c|c|c|c|c|c|c|c|c|c|c|c|c|c|c|}
\hline & $\mathrm{R}_{1}$ & $\mathrm{R}_{2}$ & $\mathrm{R}_{3}$ & $\mathrm{R}_{4}$ & $\mathrm{R}_{5}$ & $\mathrm{R}_{6}$ & $\mathrm{R}_{7}$ & $\mathrm{R}_{8}$ & $\mathrm{R}_{9}$ & $\mathrm{R}_{10}$ & $\mathrm{R}_{11}$ & $\mathrm{R}_{12}$ & $\mathrm{R}_{13}$ & $\mathrm{R}_{14}$ \\
\hline S1 & 0.5 & 1.00 & 0.5 & 0 & 0.67 & 0.33 & 1.0 & 0 & 0.5 & 0.5 & 1.0 & 0.33 & 0.5 & 0.5 \\
\hline S2 & 1.0 & 0.67 & 0 & 1.0 & 0.33 & 0.33 & 0 & 0.67 & 0.5 & 1.0 & 0 & 0.67 & 0 & 0.5 \\
\hline S3 & 0.5 & 0.67 & 1.0 & 0 & 0.67 & 0.67 & 1.0 & 0 & 0.5 & 0.5 & 1.0 & 1.00 & 0 & 0.5 \\
\hline S4 & 0 & 1.00 & 0.5 & 0 & 0.33 & 0.67 & 0 & 0.33 & 1.0 & 0.5 & 0 & 0.67 & 0 & 0.5 \\
\hline S5 & 0.5 & 0.67 & 0 & 0 & 0.00 & 0.33 & 1.0 & 0.33 & 1.0 & 0.5 & 0 & 0.67 & 1.0 & 1.0 \\
\hline S6 & 1.0 & 0.33 & 0.5 & 0 & 0.33 & 0.33 & 0 & 1.0 & 0 & 0 & 0 & 0.67 & 0.5 & 0.5 \\
\hline S7 & 0.5 & 0.00 & 0.5 & 1.0 & 1.00 & 0.00 & 0 & 0.33 & 0.5 & 0.5 & 1.0 & 0.33 & 0.5 & 0.5 \\
\hline S8 & 0 & 0.67 & 0.5 & 0 & 1.00 & 0.67 & 0 & 0.33 & 0.5 & 0.5 & 1.0 & 0.33 & 0.5 & 0 \\
\hline S9 & 1.0 & 0.67 & 0 & 0 & 0.33 & 1.00 & 1.0 & 0.67 & 0.5 & 0 & 1.0 & 0 & 0 & 1.0 \\
\hline Ref & 1.0 & 1.0 & 1.0 & 1.0 & 1.0 & 1.0 & 1.0 & 1.0 & 1.0 & 1.0 & 1.0 & 1.0 & 1.0 & 1.0 \\
\hline
\end{tabular}

The difference matrix is framed by using Equation (6) and presented in Table

6.

Table 6: Difference matrix

\begin{tabular}{|c|c|c|c|c|c|c|c|c|c|c|c|c|c|c|}
\hline & $\mathrm{R}_{1}$ & $\mathrm{R}_{2}$ & $\mathrm{R}_{3}$ & $\mathrm{R}_{4}$ & $\mathrm{R}_{5}$ & $\mathrm{R}_{6}$ & $\mathrm{R}_{7}$ & $\mathrm{R}_{8}$ & $\mathrm{R}_{9}$ & $\mathrm{R}_{10}$ & $\mathrm{R}_{11}$ & $\mathrm{R}_{12}$ & $\mathrm{R}_{13}$ & $\mathrm{R}_{14}$ \\
\hline $\mathrm{S} 1$ & 0.5 & 0 & 0.5 & 1.0 & 0.33 & 0.67 & 0 & 1 & 0.5 & 0.5 & 0 & 0.67 & 0.5 & 0.5 \\
\hline S2 & 0 & 0.33 & 1.0 & 0 & 0.67 & 0.67 & 1.0 & 0.33 & 0.5 & 0 & 1.0 & 0.33 & 1.0 & 0.5 \\
\hline S3 & 0.5 & 0.33 & 0 & 1 & 0.33 & 0.33 & 0 & 1.0 & 0.5 & 0.5 & 0 & 0 & 1.0 & 0.5 \\
\hline S4 & 1.0 & 0 & 0.5 & 1 & 0.67 & 0.33 & 1.0 & 0.67 & 0 & 0.5 & 1.0 & 0.33 & 1.0 & 0.5 \\
\hline S5 & 0.5 & 0.33 & 1.0 & 1 & 1.0 & 0.67 & 0 & 0.67 & 0 & 0.5 & 1.0 & 0.33 & 0 & 0 \\
\hline S6 & 0 & 0.67 & 0.5 & 1 & 0.67 & 0.67 & 1.0 & 0 & 1.0 & 1.0 & 1.0 & 0.33 & 0.5 & 0.5 \\
\hline S7 & 0.5 & 1.0 & 0.5 & 0 & 0 & 1.0 & 1.0 & 0.67 & 0.5 & 0.5 & 0 & 0.67 & 0.5 & 0.5 \\
\hline S8 & 1.0 & 0.33 & 0.5 & 1.0 & 0 & 0.33 & 1.0 & 0.67 & 0.5 & 0.5 & 0 & 0.67 & 0.5 & 1.0 \\
\hline S9 & 0 & 0.33 & 1.0 & 1.0 & 0.67 & 0 & 0 & 0.33 & 0.5 & 1.0 & 0 & 1.0 & 1.0 & 0 \\
\hline Ref & 1.0 & 1.0 & 1.0 & 1.0 & 1.0 & 1.0 & 1.0 & 1.0 & 1.0 & 1.0 & 1.0 & 1.0 & 1.0 & 1.0 \\
\hline
\end{tabular}

The grey relation coefficients are calculated by using Equation (7) and presented in Table 7.

Table 7: Grey relational coefficients

\begin{tabular}{|c|c|c|c|c|c|c|c|c|c|c|c|c|c|c|}
\hline & $\mathrm{R}_{1}$ & $\mathrm{R}_{2}$ & $\mathrm{R}_{3}$ & $\mathrm{R}_{4}$ & $\mathrm{R}_{5}$ & $\mathrm{R}_{6}$ & $\mathrm{R}_{7}$ & $\mathrm{R}_{8}$ & $\mathrm{R}_{9}$ & $\mathrm{R}_{10}$ & $\mathrm{R}_{11}$ & $\mathrm{R}_{12}$ & $\mathrm{R}_{13}$ & $\mathrm{R}_{14}$ \\
\hline S1 & 0.5 & 1.0 & 0.5 & 0.33 & 0.60 & 0.43 & 1.0 & 0.33 & 0.5 & 0.5 & 1.0 & 0.43 & 0.5 & 0.5 \\
\hline S2 & 1 & 0.60 & 0.33 & 1.0 & 0.43 & 0.43 & 0.33 & 0.60 & 0.5 & 1.0 & 0.33 & 0.60 & 0.33 & 0.5 \\
\hline S3 & 0.5 & 0.60 & 1 & 0.33 & 0.60 & 0.60 & 1.0 & 0.33 & 0.5 & 0.5 & 1.0 & 1.0 & 0.33 & 0.5 \\
\hline S4 & 0.33 & 1.0 & 0.5 & 0.33 & 0.43 & 0.60 & 0.33 & 0.43 & 1.0 & 0.5 & 0.33 & 0.60 & 0.33 & 0.5 \\
\hline S5 & 0.5 & 0.60 & 0.33 & 0.33 & 0.33 & 0.43 & 1.0 & 0.43 & 1.0 & 0.5 & 0.33 & 0.60 & 1.0 & 1.0 \\
\hline S6 & 1.0 & 0.43 & 0.5 & 0.33 & 0.43 & 0.43 & 0.33 & 1.0 & 0.33 & 0.33 & 0.33 & 0.60 & 0.5 & 0.5 \\
\hline S7 & 0.5 & 0.33 & 0.5 & 1.0 & 1 & 0.33 & 0.33 & 0.43 & 0.5 & 0.5 & 1.0 & 0.43 & 0.5 & 0.5 \\
\hline S8 & 0.33 & 0.60 & 0.5 & 0.33 & 1 & 0.60 & 0.33 & 0.43 & 0.5 & 0.5 & 1.0 & 0.43 & 0.5 & 0.33 \\
\hline S9 & 1 & 0.60 & 0.33 & 0.33 & 0.43 & 1.0 & 1.0 & 0.60 & 0.5 & 0.33 & 1.0 & 0.33 & 0.33 & 1.0 \\
\hline
\end{tabular}

The grey relation grades are computed by using Equation (9), as the weights are different for criteria under consideration. The weights are calculated by adopting analytic hierarchy process. An expert team was constituted comprising of five safety professionals having more than 20 years of experience in the domain of construction 
INDEPENDENT JOURNAL OF MANAGEMENT \& PRODUCTION (IJM\&P)

http://www.ijmp.jor.br

v. 9, n. 1, January - March 2018

ISSN: 2236-269X

DOI: 10.14807/ijmp.v9i1.656

safety and weights are calculated rounding off to two decimal points by using analytic hierarchy process. The values of grey relational grades are presented in Table 8.

Table 8: Grey relational grades

\begin{tabular}{|c|c|c|c|c|c|c|c|c|c|c|c|c|c|c|}
\hline & $\mathrm{R}_{1}$ & $\mathrm{R}_{2}$ & $\mathrm{R}_{3}$ & $\mathrm{R}_{4}$ & $\mathrm{R}_{5}$ & $\mathrm{R}_{6}$ & $\mathrm{R}_{7}$ & $\mathrm{R}_{8}$ & $\mathrm{R}_{9}$ & $\mathrm{R}_{10}$ & $\mathrm{R}_{11}$ & $\mathrm{R}_{12}$ & $\mathrm{R}_{13}$ & $\mathrm{R}_{14}$ \\
\hline Wts & 0.07 & 0.15 & 0.10 & 0.11 & 0.07 & 0.07 & 0.05 & 0.05 & 0.05 & 0.06 & 0.06 & 0.05 & 0.05 & 0.06 \\
\hline S1 & 0.04 & 0.15 & 0.05 & 0.04 & 0.04 & 0.03 & 0.05 & 0.02 & 0.03 & 0.03 & 0.06 & 0.02 & 0.03 & 0.03 \\
\hline S2 & 0.07 & 0.09 & 0.03 & 0.11 & 0.03 & 0.03 & 0.02 & 0.03 & 0.03 & 0.06 & 0.02 & 0.03 & 0.02 & 0.03 \\
\hline S3 & 0.04 & 0.09 & 0.1 & 0.04 & 0.04 & 0.04 & 0.05 & 0.02 & 0.03 & 0.03 & 0.06 & 0.05 & 0.02 & 0.03 \\
\hline S4 & 0.02 & 0.15 & 0.05 & 0.04 & 0.03 & 0.04 & 0.02 & 0.02 & 0.05 & 0.03 & 0.02 & 0.03 & 0.02 & 0.03 \\
\hline S5 & 0.04 & 0.09 & 0.03 & 0.04 & 0.02 & 0.03 & 0.05 & 0.02 & 0.05 & 0.03 & 0.02 & 0.03 & 0.05 & 0.06 \\
\hline S6 & 0.07 & 0.06 & 0.05 & 0.04 & 0.03 & 0.03 & 0.02 & 0.05 & 0.02 & 0.02 & 0.02 & 0.03 & 0.03 & 0.03 \\
\hline S7 & 0.04 & 0.05 & 0.05 & 0.11 & 0.07 & 0.02 & 0.02 & 0.02 & 0.03 & 0.03 & 0.06 & 0.02 & 0.03 & 0.03 \\
\hline S8 & 0.02 & 0.09 & 0.05 & 0.04 & 0.07 & 0.04 & 0.02 & 0.02 & 0.03 & 0.03 & 0.06 & 0.02 & 0.03 & 0.02 \\
\hline S9 & 0.07 & 0.09 & 0.03 & 0.04 & 0.03 & 0.07 & 0.05 & 0.03 & 0.03 & 0.02 & 0.06 & 0.02 & 0.02 & 0.06 \\
\hline
\end{tabular}

Basing on the overall performance of safety officers on various criteria according to grey relation grades are presented in Table 9. The rankings were given basing on the total grey relation grades.

Table 9: Rankings of safety officers basing on overall grade of GRA

\begin{tabular}{|c|c|c|}
\hline Safety officer & Total of grades & Rank \\
\hline S1 & 0.62 & 2 \\
\hline S2 & 0.60 & 4 \\
\hline S3 & 0.64 & 1 \\
\hline S4 & 0.55 & 7 \\
\hline S5 & 0.56 & 6 \\
\hline S6 & 0.50 & 9 \\
\hline S 8 & 0.58 & 5 \\
\hline S9 & 0.54 & 8 \\
\hline
\end{tabular}

\subsection{Results of TOPSIS}

The final ranking as per TOPSIS based on the relative closeness index is presented in Table 10.

Table 10: Rankings of safety officers basing on TOPSIS

\begin{tabular}{|c|c|c|}
\hline Safety officer & Relative closeness coefficient & Rank \\
\hline S1 & 0.4607 & 3 \\
\hline S2 & 0.1407 & 4 \\
\hline S3 & 0.8741 & 1 \\
\hline S4 & 0.0856 & 7 \\
\hline S5 & 0.1022 & 6 \\
\hline S6 & 0.0032 & 9 \\
\hline S8 & 0.1057 & 5 \\
\hline S9 & 0.0432 & 8 \\
\hline
\end{tabular}


The rank correlation between the two methods is calculated and found to be 0.92 and strong correlation exists between the ranks obtained in both the methods.

\section{CONCLUSIONS}

The role of safety officer is in any organization is critical otherwise it effects the safety performance drastically. Selection of safety officer is a crucial decision making process and it depends on the scope of the work. In Indian construction organizations, traditional methods are being followed for selection of safety officers. The process of selection is based on several criteria relating to safety and application of multi criteria decision making tools in selection is useful to the organizations.

Some firms use traditional methods based on their intuitions in recruitment process while the others prefer more scientific methods. In this paper, GRA method is proposed for selection of safety officers by considering fourteen criteria to overcome the drawbacks of the traditional methods, which are based on subjective judgment of decision makers. The criteria considered in the study are equally important to improve the safety performance of an organization.

In the present study two methods are used; GRA and TOPSIS. Initially the data was analyzed by using GRA, which is simple method to apply and easy to understand. TOPSIS method was applied to compare the rankings obtained by using the GRA method and found that strong correlation exists between the two methods in final rankings. The rankings of eight safety officers who attended the selection process remain same except safety officer 1 (S1). The best candidate for the safety officer position is S3, as ranking is same in both the methods. The accuracy of the rankings obtained is consistent and strong association is exists between the methods.

\section{References}

AMIT,C.; INDU, U. (2013) Identification of Telecom Service Quality Dimensions in India with Fuzzy Analysis, Global Journal of Management and Business studies, v. 3, n. 5, p. 467-474.

ANJALI, A.; CHAUHAN, S. S.; GOYAL, S. K. (2011) A Multi - criteria Decision making Approach for Location Planning for Urban Distribution Centres Under Uncertainty, Mathematical and Computer Modelling, v. 53,n. 2,p. 98-109. 
BERIHA, G. S.; PATNAIK, B.; MAHAPATRA, S. S. (2011) Measuring the perception of safety officers on occupational health in Indian industries, International Journal Indian Culture and Business Management, v. 4,n. 1, p. 30-47.

BERNA, B. (2012) Application of TOPSIS Technique for Financial Performance Evaluation of Technology Firms in Istanbul Stock Exchange Market. Procedia Social and Behavioral Sciences, v. 62, p. 1033-1040.

BIRGUIN, S.; GUNGOR, C. (2014). A multi-criteria call center site selection by hierarchy grey relational analysis. Journal of Aeronautics and Space Technologies, v. 7, n. 1, p. 45-52.

CHAN, J. W.; TONG, T. K. (2007). Multi-criteria material selections and end-of-life product strategy: Grey relational analysis approach. Materials \& Design, v. 28, n. 5, p. 1539-1546.

DAGDEVIREN, M. (2010) A hybrid multi-criteria decision making model for personnel selection in manufacturing systems, Journal of Intelligent Manufacturing, v. 21, p. 451-460.

DRAGISA, S.; BOJAN, D.; MIRA, D. (2013) Comparative Analysis of Some Prominent MCDM Methods: A Case of Ranking Serbian Banks. Serbian Journal Management, v. 8, n. 2, p. 213-241.

GIBNEY, R.; SHANG, J. (2007) Decision making in academia: A case of the dean selection process, Mathematical and Computer Modelling, v. 46, n. 7-8, p. 10301040.

GOVERNMENT OF INDIA.(1996) The Building and Other Construction Workers (Regulation of Employment and Conditions of service) Act, 1996.

HADI, S.; MAZDAK, K.; REZA, D. (2011) Prioritizing Critical Success Factors Influencing Safety Using TOPSIS, International Journal of Business and Social Science, v. 2, n. 20, p. 295-300.

HASHEMI, S. H.; KARIMI, A.; TAVANA, M. (2015). An integrated green supplier selection approach with analytic network process and improved Grey relational analysis. International Journal of Production Economics, v. 159, p.178-191.

IRFAN, E.; TAYFUN, O.; ABDULLAH, O.; GULIN, Z. (2016) Grey Relational Analysis Approach In Academic Performance Comparison Of University: A Case Study Of Turkish Universities, European Scientific Journal, p. 128-133.

KANCHANA, P.; GAYANI, K.; SAJANI, J. (2013) Construction Safety Assessment Framework for Developing Countries: A Case Study of Sri Lanka, Journal of Construction in Developing Countries, v. 18, n. 1, p. 33-51.

KUO, Y.; YANG, T.; HUANG, G. W. (2008). The use of grey relational analysis in solving multiple attribute decision-making problems. Computers \& Industrial Engineering, v. 55, n. 1, p. 80-93.

LIANG, S. L.; Wang, M. J. (1994) Personnel selection using fuzzy MCDM algorithm, European Journal of Operational Research, v. 78, p. 22-33.

MARKABI, M. S.; SABBAGH, M. (2014) A Hybrid Method of GRA and DEA for Evaluating and Selecting Efficient Suppliers plus a Novel Ranking Method for Grey Numbers, Journal of Industrial Engineering and Management, v. 7, n. 5, p. 11971221. 
NILSEN, K. (2016) Personnel selection with grey relational analysis. Management Science Letters, n. 6,p. 351-360.

PIJUSH, K. B.; TITHARAJ, S.; DEBAMALYS, B.; BIJAN, S.(2012) Analysis of Noise Emitted from Electrical Machines Using TOPSIS Technique, International Journal of Environment Science and Development, v. 3, n. 1, p. 5-9.

PPARAWAN, P. (2015) Application of the Multi Criteria Decision Making Methods for Project Selection. Universal Journal of Management, v. 3, n. 1, p. 15-20.

PRAMANIK, S.; MUKHOPADHYAYA, D. (2011) Grey Relational Analysis based Intuitionistic Fuzzy Multi-criteria Group Decision-making Approach for Teacher Selection in Higher Education, International Journal of Computer Applications, v. 34,n. 10, p. 21-29.

RAJESH, R.; RAVI, V. (2015). Supplier selection in resilient supply chains: a grey relational analysis approach. Journal of Cleaner Production, v. 86,p. 343-359.

ROBERTSON, I.T.; SMITH, B. (2001) Personnel selection, Journal of Occupational and Organizational Psychology, v. 74, p. 441-472.

ROGHANIAN, E. A.; EHSAM, S. A. (2014) An Application of Fuzzy TOPSIS to Improve the Process of Supply Chain Management in the Food Industries: A Case Study of Protein Products Manufacturing Company, Decision Science Letters, v. 3, n. 1, p.17-26.

ROUYENDEGH, B.; ERKAN, T. (2012) Selection of academic staff using the fuzzy analytic hierarchy process (FAHP): a pilot study, Tehnicki vjesnik-Technical Gazette, v. 19, n. 4, p. 923-929.

SIFEN, L.; FORREST, J. (2007) The Current Developing Status on Grey System Theory, The Journal of Grey System, v. 2, p. 111-123.

SUN, C.; XIANG, S.; JIANG, S. (2015) A Supply Chain Risk evaluation Method Based on Fuzzy TOPSIS, International Journal of Safety and Security Engineering, v. 5, n. 2, p. 150-161.

SUNITHA, G.; RUBEN, P. (2017) A Grey Based Decision Making Approach for Supplier Selection, IOSR Journal of Business and Management, v. 19, n. 3, p. 7275.

TSAI, C. H.; CHANG, C. L.; CHEN, L. (2003). Applying grey relational analysis to the vendor evaluation model. International Journal of The Computer Internet and Management, v. 11, n. 3,p. 45-53.

WANG, Y.; XI, C.; ZHANG, S.; YU, D. (2015) Combined Approach for Government ETendering Using GA and TOPSIS with Intuitionist Fuzzy Information, PLoS ONE, v. 10, n. 7, p. 1-20.

XU, G.; YANG, Y. P.; LU, S. Y.; LI, L.; SONG, X. (2011). Comprehensive evaluation of coal-fired power plants based on grey relational analysis and analytic hierarchy process. Energy Policy, v. 39,n. 5,p. 2343-2351.

YANG, C. C.; CHEN, B. S. (2006). Supplier selection using combined analytical hierarchy process and grey relational analysis. Journal of Manufacturing Technology Management, v. 17,n. 7,p. 926-941. 
ISSN: 2236-269X

DOI: 10.14807/ijmp.v9i1.656

YONG-TAO, T.; LI-YIN, S.; CRAIG, L.; YAN, L.(2010) Construction Project Selection Using Fuzzy TOPSIS Approach, Journal of Modelling in Management , v. 5, n. 3, p. 302-315. 